\title{
Correction to: Morphometric analysis of the Idemili Basin using geospatial techniques
}

\author{
Christopher Uche Ezeh ${ }^{1} \cdot$ Arinze Tagbo Mozie ${ }^{1}$
}

Published online: 26 April 2019

(C) Saudi Society for Geosciences 2019

Correction to: Arabian Journal of Geosciences (2019) 12:208 https://doi.org/10.1007/s12517-019-4336-x

Table 1 Stream Numbers, order and Bifurcation ratio

\begin{tabular}{lll}
\hline Stream Order $(\mathrm{u})$ & Stream number $(\mathrm{Nu})$ & Bifurcation Ratio $\mathrm{R}_{\mathrm{b}}$ \\
\hline 1 & 104 & 5.2 \\
2 & 20 & 6.67 \\
3 & 3 & 3.00 \\
4 & 1 & - \\
Total & 128 & $R_{b}=\mathbf{4 . 9 6}$ \\
\hline
\end{tabular}

From Table 1, the mean bifurcation ratio is $\mathbf{4 . 9 6}$.

Table 2 The stream orders, lengths and length ratio

\begin{tabular}{lll}
\hline Stream order $(\mathrm{u})$ & Stream length $(\mathrm{Lu})$ & Length ratio \\
\hline 1 & 142.05 & 1.89 \\
2 & 75.16 & 3.50 \\
3 & 21.45 & 0.86 \\
4 & 24.87 & - \\
Total & 263.53 & $\mathrm{R}_{\mathrm{L}}=\mathbf{2 . 0 8}$ \\
\hline
\end{tabular}

Slope, maximum and minimum height.

The maximum height is $\mathbf{3 8 5} \mathrm{m}$ above mean sea level, the minimum is $\mathbf{2} \mathrm{m}$ amsl and the mean is $\mathbf{1 6 8 . 2 4} \mathrm{m}$. It shows that the areas surrounding the stream channels have very low elevation.

The online version of the original article can be found at https://doi.org/ 10.1007/s12517-019-4336-x

\footnotetext{
Christopher Uche Ezeh

christopher-uche.ezeh@unn.edu.ng
}

1 Department of Geography, University of Nigeria, Nsukka, Nigeria 